\title{
The Economic Impact of Corporate Governance in Saudi Arabia Economy
}

\author{
Alotaibi Mohamed Meteb \\ Associate Prof. Al-imam Muhammad Ibn Saud Islamic University - College of Economic and Administrative \\ Sciences- department of Economic
}

\begin{abstract}
The corporate governance concept has a great importance due to the financial declines and economic crises which several states have witnessed in the money markets and corporations located in a number of states in East Asia, Latin America and Russia during the 1990s of the twentieth century. Furthermore, the US economy has lately witnessed financial and accounting declines and the world financial crisis of 2008-2009 whose one of its most important reasons is related to the lack of transparency and disclosure of the financial and accounting data of a number of corporations and economic units of the money markets. Definitions of corporate governance are varied according to the different adopted viewpoints related to the research scope. Governance can be defined as the corporations' rational governance through a group of laws, rules and bases that guarantee transparency and law enforcement. This Paper aims to identify the various concepts of governance and state the motives behind adopting this new trend while clarifying the main features and objectives of governance, the fundamentals upon which governance is based and the internal and external determinants the control the performance of governance. The study aims as well to review the most important criteria and different principles of governance in light of the institutional framework that organizes its work nature, the international endeavors to activate it. The study aims also to identify the status quo of the corporate governance in Saudi Arabia. The Paper relies on the descriptive method and depends on theoretical library researches and the literature review in this field. Finally, the study introduces its concluded results and recommendations.
\end{abstract}

\section{Introduction}

Over the past few decades the corporate governance concept has had a great importance due to the financial declines and economic crises which several states have witnessed in the money markets and corporations located in a number of states in East Asia, Latin America and Russia during the 1990s of the twentieth century. Furthermore, the US economy has lately witnessed financial and accounting declines and the world financial crisis of 2008-2009 whose one of its most important reasons is related to the lack of transparency and disclosure of the financial and accounting data of a number of corporations and economic units of the money markets (Al-Essawy, Ibrahim, 2003).

The corporate governance concept refers to a group of organizing, administrative, legal and financial frameworks that organize the relationship between the administration and the owner (investors and shareholders) and other beneficiaries. The concept includes as well the structure through which the corporate objectives are devised with clear determined paths to how to achieve such objectives and the performance surveillance systems. The good governance system should include suitable incentives for management so that objectives can be achieved.

Research problem: Today, the developing countries are facing a fundamental challenge represented in how to transfer from governance systems based on the relationships basis to governance systems based on laws basis. Some economists still view corporate governance as relatively unimportant in the developing countries due to the limited number of corporations that have current shares. The decline of more economic units has led to wasting the rights of their beneficiaries particularly the current investors and to losing the trust among the awaiting investors in the accounting information included in the reports and financial statements of these units. The corporate governance implementation depends on the cooperation between private and public sectors and the extent to which the legislative authority is strong to enforce the corporation adopting its implementation.

Research Objectives: The research aims to identify the various concepts of governance and state the motives behind adopting this new trend while clarifying the main features and objectives of governance, the fundamentals upon which governance is based and the internal and external determinants the control the performance of governance. The study aims as well to review the most important criteria and different principles of governance in light of the institutional framework that organizes its work nature, the international endeavors to activate it. 
The study aims also to identify the status quo of the corporate governance in Saudi Arabia and its successful implementation. Finally, the study introduces its concluded results and recommendations.

Research Significance: Since 1997 and with the breaking of Asian Financial crisis and its subsequent world financial crises, the world has adopted a new vision towards corporate governance and the abovementioned financial crisis. That crisis could be described as a crisis of trust in the institutions and legislations that organize the business activity and the relationships among business establishments and the government. The latest events- starting from the Enron company scandal and the subsequent discovered chain of manipulation, on the part of the company, of its financial statements- have clarified the importance of corporate governance even in the countries which are usually considered as nearly perfect financial markets. As such there is an emphasis on the effective role of that term and its included means of treatment and reforms for such declines and crises.

Research Methodology and Technique: The research relies on the descriptive method to describe, interpret and analyze the findings of other studies relevant to its thesis statement, in order to determine their concluded results and how to make use of them in overcoming the research problem.

Research Hypotheses: The effective implementation of governance is conditionally linked to the ethical and empirical reform of legislative infrastructure and the existence of democratic atmosphere and social equity. Therefore, the implementation of governance's sound principles leads to creating the necessary precautions against corruption and ill-administration.

Research Plan: The research divided into the following parts:

Part One: Concept, Features and Motives of the corporate governance trend.

Part Two: Objectives, Fundamentals, Criteria and determinants of corporate governance.

Part Three: Stats Quo of corporate governance in Saudi Arabia.

Part Four: Results and recommendations.

Part One: Concept, Features and Motives of the corporate governance trend.

- Concept and Nature of Corporate Governance: Definitions of corporate governance are varied according to the different adopted viewpoints related to the research scope. Governance can be defined as the corporations' rational governance through a group of laws, rules and bases that guarantee transparency and law enforcement (Youssif, Mohamed, 2007).

Laporta and Shleifer, 1997 clarified that the issue of corporate governance's legislations and laws has tangible effect on the corporation's efficiency and performance. Corporate governance is a group of principles, rules, systems, procedures and laws that govern the relationships among the main parties, corporations' administrations, shareholders, beneficiaries, disclosure and surveillance systems. Therefore, governance influences the corporation's performance and aims to achieve quality, improve performance rates through devising the plans and objectives of such corporations. Governance includes as well determining the administration's appropriate incentives in order to achieve its objectives in a way that serves the shareholders' interests and encourage them to implement the transparency principle and avoid interests conflict and other unaccepted ethical and administrative conducts within the surveillance systems over the corporations' administrations and their members of boards of directors. In addition, governance assigns the rights and responsibilities among the boards of directors, shareholders and implements procedures that determine the corporations' work performance in order to achieve the governance objectives.

The international financing corporation (IFC) defines governance as a system through which the corporation's administration is conducted and its businesses are controlled (Alamgir, M. (2007).The Organization for Economic Cooperation and Development (OECD) defines governance as a group of relationships among those in charge of administering the corporation, the board of directors, shareholders and other contributors (Freeland, C. (2007). The international corporations have adopted and developed the governance concept in the late 1980s in order to denounce extravagancy and waste in managing the public money on the part of some developing countries' governments. The World Bank, in this regard, decides on the good governance because of its "authority in providing the state's socioeconomic resources necessary for development." Governance means the attempt to fill in the potential gaps through which corruption may creep into the private or public economic institutions. The World Bank reports2012 estimate the annual paid briberies as $\$$ one trillion, about $\$ 2.77$ billion daily at the world level. It is a great figure as compared to the world economic volume estimates \$ 30 trillion annually.

- $\quad$ Features of Corporate Governance: According to the UN development program of 2005, governance has certain features and pillars, namely:

- $\quad$ sharing of all men and women as a main stone of good governance. Sharing could be directly or through representative, meddling and legal corporations. 
- The good governance requires just legal frameworks neutrally implemented and full observation of human rights as well. The just implementation of law requires independent judiciary and unbiased and uncorrupted police.

- Transparency: it means that the decision-making process and its implementation are carried out according to specific rules. It also means the information is available and accessible to those affected by the decisions' implementation. Furthermore, it means the information is available in clear forms through the mass media.

- Agreement and unanimity: there are several doers and visions in the society. The good governance requires the mediation of various interests in society in order to conclude a broad agreement regarding what may constitute the common interest for the society at large and the means of its achievement.

- The reform of society depends on ensuring that all its members have equally shared in it not they have been excluded from the society's main current.

- The good governance means the results of processes and corporations are consistent with the needs of the society through the optimal use of its sources(Efficiency). The efficiency concept includes as well the current use of the natural resources' continuity and environment reservation.

- Accountability: not only is accountability a mile stone of the good governance for the public sector corporations, but also for the private sector corporations and the civil society organizations which should subject to accountability before the society and those in charge of the corporations.

- Strategic vision: the leaders, the public and those in charge of administering the corporations should possess long-term vision for good governance and development in parallel with the requirements of that development.

There is a close relationship between good governance and development process. The good governance has become in its all dichotomies a main condition to achieving the continued development through creating the political, legal, economic and social circumstances necessary for liberating these human abilities and hence reinforcing the human welfare through eliminating poverty, creating job opportunities, preserving environment and elevating the position of women.

- Motives and importance of corporate governance trend: The international business establishments, international financing corporation and development programs have laid great importance to corporate governance due to the events that took place during the last two decades and were the main reason behind the concern of this issue. The need for governance has appeared in several advanced and emerging economies during the last few decades particularly after the occurrence of economic declines and financial crises in a number of Southeast Asian countries, Latin America and Russia during the 1990s of the last century. Its appearance is also attributed to the financial and accounting declines which the US economy has recently witnessed during 2002 and the world financial crisis of 2008/2009(The National Bank of Egypt, 2003).

Some examples of private corporations that contributed to talks increase about governance because of corruption: Enron, Anderson, Rolled COM, the roles of banks and institutions in breaking out the Southeast Asian crisis in 1997, financing funds, some energy corporations, pension funds of corporations' employees, General Electric corporation, Fiat corporation, Universal Vivindy corporation. Enron corporation has not adhered to disclosure and auditing because of using complicated accounting techniques aim to shroud overdependence on loans in financing its activity and conceal its revenues.

The importance of corporate governance has increasingly grown due to the trend adopted by several world countries to transfer into the capitalist-based economic systems in which the private companies are heavily relied on to achieve higher and continued rates of economic growth. The expansion of such projects volumes has led to the separation of equity from administration.

Furthermore, globalization, financial markets liberalization and the opening up of new world markets, which provide the potentiality of achieving higher profits, have a great role in the motives behind corporate governance. Weakness of legal system with which contracts enforcement cannot be carried out and disputes cannot be effectively resolved besides weak information that led to prohibiting surveillance and control, a matter that led in turn the spread of corruption and non-existence of trust(Fawzy, S. 2003). Continued increase of popular corruption causes in the mega corporations like the US Enron corporations.

Part Two: Objectives, Determinants and Criteria of Corporate Governance.

- Objectives and Benefits of Corporate Governance: The rules and constraints of corporate governance aim to achieve transparency, justice and to grant the right of holding the corporation administration accountable. Consequently, they preserve the rights of all shareholders and securities holders with taking into consideration the business and workers' interests. They also curb the misuse of power in a way which against the public interest, a matter that leads to developing the investment, encouraging the investment flow, developing the savings, engrossing the profitability and providing new job opportunities. Corporate governance increases the 
confidence in national economy, deepens the money market's role and increases its capacity in mobilizing savings, increases the investment rate and preserves the rights of minorities and small investors. On the other hand, the corporate governance encourages the growth of private sector and strengthens its competitiveness, helps the enterprises get necessary financing and generates profits and finally creates job opportunities.

These rules emphasize the importance of adhering to judgments of the laws; ensure the review of financial performance and the existence of administrative structures that facilitate the administration accountability before shareholders. These rules also help create auditing committees which comprise executive non-member of board of directors. Such committees have several tasks, specializations and authorities to achieve independent surveillance over performance. Good governance leads to risk reduction- performance reinforcement- the improvement of financial market accessibility- the increase of goods and services marketability- the improvement of leadership- the prominence of transparency and social accountability. Good corporate governance, in the form of financial information disclosure, may help reduce the establishment's capital cost, attract foreign or domestic investments, curb capital inflow, fight against corruption which everyone realizes nowadays the extent to which corruption can impede growth.

The corporate governance depends, finally, on the cooperation between the public and private sectors for creating competitive-market system in a democratic society established of the basis of law. This could be achieved through the consideration of economic structures and structures of works that reinforce the private sector's competitiveness and encourage the attraction of foreign direct investment.

- The Criteria Governing the Corporate Governance Process: Because of the increasing concern of governance concept, several institutions have shown interest in studying, analyzing the concept and setting limited criteria for its implementation. Among these institutions are the Organization for Economic Cooperation and Development (OECD), Bank of International Settlements (BIS) represented by Basel Committee and the international financing institution affiliated to the World Bank. Indeed, whenever the governance's introduced definitions differ, the criteria governing the process of governance differ as well due to the different perspectives and viewpoints that set the criteria. For instance:

Criteria of the Organization for Economic Cooperation and Development (OECD) include the following principles (Charles P. Oman, 2005):

- Shareholders rights: They include a group of rights ensuring secure ownership of shares, the shareholder right of ample disclosure of information, voting rights, participation in the decision of selling or modifying the corporation's assets including merger and the issue of new shares.

- Equal treatment of shareholders: The Organization for Economic Cooperation and Development pays attention to the protection of minor shareholders' rights through establishing systems that prevent employees within the corporation including the managers and members of board of directors from benefiting from their distinguished positions.

- Other beneficiaries' role in the corporate governance: The Organization for Economic Cooperation and Development acknowledges the existence of other beneficiaries rather than the shareholders such as banks, bonds holders and employees who are important beneficiaries to the corporation's methods of conducting work and making decisions.

- Disclosure and transparency: the Organization for Economic Cooperation and Development has devised a number of texts for disclosure and report on the corporation's related fundamental facts. These facts contain the financial details and governance structures including the board of directors and the bounces whose members obtain. The guidelines define as well the necessity of annual auditing by two independent auditors according to the highest criteria of quality.

- Responsibilities of board of directors: The guidelines provide a great part of details related to the tasks of board of directors in protecting the corporation, its shareholders and other beneficiaries. They include other matters related to the corporation's strategy, risks, the performance of executive employees and their salaries, accounting systems and preparation of reports (OECD, 2004).

Criteria of Basel committee for world banking surveillance: In 1992, Basel committee devised guidelines related to the governance of financial and banking institutions. These guidelines focus on the following points (Youssif, Mohamed, 2007):

- The corporation's values, conventions of ethics for good conduct and other good conduct criteria and systems whose use lead to the implementation of such criteria.

- The corporation's well-prepared strategy according to which its total success and the individuals' contribution to that success could be measured.

- Sound distribution of responsibilities and the decision-making positions including the hieratical series of members of board of directors for required approvals.

- Setting up an effective cooperation mechanism between the board of directors, the accounts auditor and the higher administration. 
- The existence of strong inner disciplinary system including the inner and outer auditing tasks and a risk independent administration while observing the consistency of authorities to responsibilities.

- Special surveillance of the risk positions in the sites where conflict of interest is growing including the deal with bank's associated borrowers, great shareholders, the higher administration or the main-decision makers at the corporation.

- Financial and administrative incentives of the highest administration that soundly perform the work and the incentives of managers, employees as well whether they are in the form of compensations, promotions or other elements.

- Proper inflow or outflow of information.

Criteria of the International Financing Institution: The international financing institution affiliated to the World Bank has determined in 2003 general and fundamental rules and criteria for supporting the corporate governance at different institutions whether they are financial and non-financial institutions. These rules and criteria include four levels namely(Fawzy, S., 2003):Acceptable practices of good governance, Additional steps for ensuring the new good governance, Main contributions for locally improving the good governance, and Leadership.

The raised question is: can common criteria and measures of governance be adopted at the world level? The answer is: governance principles should be adapted and modified in consistence with domestic needs as a measure cannot suit all countries. The implementation of internationally accepted accounting criteria should be openly required along with elevating the level of national criteria to a consistent level with the international criteria. The corporation's inner auditing tasks should be clarified along with open stipulation of joining the outer members of board of directors to the auditing committees.

- Fundamental determinants of corporate governance: There is an agreement that the implementation or nor of good corporate governance depends on the extent of realizing the quality level of two determinants groups, namely the internal and external determinants (Iskander, M. and N.Chamlou, 2002, Fawzy, S., 2003):

The External Determinants: They refer to the general investment environment in the state, which includes for instance, laws that organize the economic activity (such as laws of money market, corporations, organizing competition, prevention of monopolized practices and bankruptcy). That environment refers as well to the financial sector's efficiency (banks and money markets) in providing the financing necessary for projects, the competitiveness ratio of commodities and production elements markets, efficiency of surveillance authorities and bodies (money market corporation and the stock market) in tightening surveillance over corporations and some self-organizing corporations that ensure the markets' efficiency (for example, the professional associations that devise the ethics code for the employees in the markets such as auditors, accountants, lawyers, corporations working at the stock markets and others). In addition, that environment includes the private-free profession institutions such as bureau of lawyers, auditing, credit rating and financial and investment consultation). The importance of external determinants is attributed to the fact that their existence ensures the implementation of laws and rules which ensure the corporation's well-management that lessens the contrast between the social return and private return.

The Internal Determinants: They refer to the rules and laws determining the ways of decision-making, the authority distribution within the corporation between the general assembly, board of directors and executive managers. The existence of such determinants on the one hand and their implementation on the other hand lead to lessening the contrast between the three parties' interests.

There are two necessary elements for the activation of prudent governance (The Committee for the Coordination of Statistical Activities, 2005). The first element represents the necessity of providing new statistics and information produced by a national efficient and effective system of statistics and information as the statistical system quality and its information and statistics output are considered a fundamental part of good prudent governance. The second element represents the information accessibility right and the public's right to get acquainted to such information. The activation of governance and guarantee of its well implementation require comprehensive and accessible information and statistics available to all members of the society, as the accessibility and free circulation of information are two of the main governance's pillars.

The international community has stated as well the importance of information accessibility for other reasons. The UN Anti-Corruption Treaty, endorsed in 2003, calls for the governments to allow the public to access information as a means of fighting against corruption.

- Institutional Framework of Effective Corporate Governance: The systems of corporate governance rely on a group of legislations (laws, regulations, contracts and rules) which enable the self-governing establishments to work as the main component of the competitive market economy. These legislations help ensure the implementation of internal corporations' governance, the administration's liability before the corporations owners (shareholders) and other beneficiaries. The public and private sectors should work together to 
devise a group of binding rules for all. They should also devise self-governance methods for the corporations. Below is a description for a group of institutions and legislations whose existence provides a tangible effect for internal governance constraints. Clearly, each state needs to evaluate its weakness aspects and take suitable remedial procedures (Report of Arab Humanity Development, 2005):

- One of the most important main legislations and the most important for establishing democratic economy based on the market basis, to set procedures for corporations' governance is the equity rights system which leads to private ownership rights.

- In the absence of legislations and regulations which ensure the soundness and verification of contracts, there would be a very few number of commercial processes that could be conducted. One of the main advantages is that these legislations protect suppliers, debtors, business owners, workers and others.

- The existence of a healthy and sound banking system is one of the main absolute pillars for the sound business of the stock market and the corporations sector. The existence of good governance in the banking sector is particularly important in the developing countries (BIS, 2006).

- the existence of Competitive markets is considered as one of the important components of external surveillance over corporations, which force corporations achieve the efficiency and productivity in fear of losing or reducing its mark allocation. The lack of competitive market existence leads to the deterioration of business organization and reinforcement of administration and corruption's strength and the reduction of productivity, In addition the need to transparent and just privatization procedures.

- The tax systems should be reformed in such a way that clarity, simplicity and accuracy become some of their characteristics. The laws and regulations should require an adequate amount of financial information's disclosure and should be effectively and permanently implemented in certain times.

- Existence of independent judiciary system that performs well: it is considered as one of the most important institutions in the democratic economy which is based on the market basis.

- It is necessary to reform the government bodies and administrations which have become over bureaucratic and inefficient.

- Strengthening and sustaining the administrative power and the executive capacity of the governmental bodies: providing the mechanic and technical resources necessary for quick and effective implementation of laws and providing modern technology based vocational training programs for civil employees, paying attractive salaries to attract efficient and qualified civil individuals and prevent bribery taking.

- Adopting sound relationship with the beneficiaries for the establishment's interest: Some believe (Sadik, Afifi, 2003) that the target of achieving profits contrasts with caring for the beneficiaries affairs (beneficiaries comprise employees, debtors, suppliers, clients, environment experts and members of society in general). Studies have shown (International Transparency Organization, 2005) the most successful corporations in the world are the ones that adopt clear business, liability and transparency along with accountability towards shareholders and beneficiaries. This helps improve the corporation's reputation, attract investors and give a competitive advantage to the corporation.

- The observation of Global Sullivan Principles that provide valuable recommendations for business and aim to reinforce the establishment of more transparent, liable, equal and accountable environment .

- International Endeavors for Sustaining and activating corporate governance: The advanced industrial communities have realized that investment attraction and international competition requires the necessity of reforming and reshaping governance. Therefore, the United Kingdom Cadbury Committee, the Franc-based Vieno Committee, the Organization for Economic Cooperation and Development (OECD) and the South Africa based King Committee for corporate governance have all issued recently new guidelines for corporate governance (Hesil, Mark, 2001).

The corporate governance's improvement efforts have started by laying out international criteria since 15 years and recently acquired lots of improvements. The World Trade Organization (WTO) and its member states have led that trend.

In addition, the World Bank and most regional banks of development, various corporations, national development authorities and OECD principles have recently launched or expanded corporate governance programs during the last years. Similarly, the business-relevant institutions such as center for private enterprises (CIPE) - affiliated to the US chambers of commerce- have placed corporate governance on the top of its concerns. The Think Tank Centers, labors unions and syndicates all over the developing world and transitional economies have focused their resources on corporate governance (Hesil, Mark, 2001).

The good governance's indicators consist of the following dichotomies (Christopher Scott, 2005):

- Voice and accountability: these indicators measure the political and civil rights besides the human rights.

- Political stability: these indicators measure the possibilities of political change and the threat of violence including terrorism. 
- Government effectiveness: these indicators measure the spread of bureaucracy and the types of offered services.

- Regulatory quality: these indicators measure the effects of non-market policies on the good governance's framework.

- Rule of law: these indicators measure the commitment and strength of law enforcement and the role of courts.

- Control of corruption: these indicators measure the misuse of power to get personal gains and benefits including the different aspects of government's corruption.

- Is corporate governance restricted only on the private sector?: Among the most important challenges that face the developing, emerging and transitional economies is to the public establishments can adopt corporate governance. The public sector's corporations in certain developing countries have the greatest share of contribution in the gross national product, employment, income and the use of capital, in a manner which exceeds the contribution of the private sector' corporations. The public sector's establishments often constitute the public policies of these countries. Therefore, the adoption of corporate governance within the public sector is considered as a main matter for economic development, growth and reform (Azab, B., 2007).

The raised question is: in the case of public sector corporations' success in implementing governance rules and achieving economic efficiency criteria, so why does the privation trend of such corporations exist currently and in the future? The answer is: these corporations of the public entrepreneur sector may achieve short-term efficiency and will not be able to resist for a long term because of the negative practices of some political and administrative leaderships. Such practices encourage the corporations to deviate from the right path. Therefore, they can more easily leave the market in the process of selling than implementing governance. This trend depends on the general atmosphere in the state.

- Governance of family-owned corporations and their transformation into public venture corporations:

Family-owned corporations are owned and managed by a family that gained its reputation from the corporation or vice versa. They are restricted to small and medium enterprises and have multi-legal forms such as (limited responsibility company, consolidation, simple trust, shares trust, and private or closed venture corporation). On the other hand, public venture corporations offer some of their share for public subscription, whereas the closed venture corporations do not offer their shares for public subscription because of the founders' full subscription of all shares.

The features of family-owned corporations: Internationally the family-owned corporations represent 85 percent of the registered corporations, contribute to 75 percent of the world gross product and employ 60 percent of the world labors. They can hardly get extinct or suspended because of their easiness and simplicity of their establishment; they exist as long as the founders or inheritors exist (Charles P. Oman, 2005).

The most important external challenges that face family-owned corporations are globalization, merge, multinational corporations, World Trade Organization or GATT, technology revolution.

The most important internal challenges that face family-owned corporations:

- The problems of presidency transfer after the founder's demise, the conflict over authority and administration, the change of ownership pattern and the generation succession problem. The number of corporations transferred to the second generation does not exceed 30 percent while their average duration does not exceed 25 years.

- Weak strategic planning of these corporations.

- Ownership can be hardly separated from these corporations.

These challenges size differ from a country to another according to the dominant economic system, the private sector's role and so on.

International regional organizations have adopted these corporations' developing initiatives to face the abovementioned challenges. These organizations are international financing institution, center for international private enterprises, academy of family-owned corporations based in Jeddah, Arab organization for administration development, some unions of chambers of commerce, associations of family-owned corporations in certain countries. The development mechanisms are the restructure of family-owned corporations, strategic alliances, merger of domestic corporations and transformation into public venture corporations (Azab, B., 2007).

The raised question is: Do family-owned corporations accept these trends? Indeed, the adherence of familyowned corporations to the realized gains, social reputation and weak trust of public venture corporations may constitute a stumbling stone before their transformation process into public venture corporations. This is attributed to the fact that the family may lose its social position, the fear of others' dominance over the administration and the family's isolation from the realized achievements over long years. In such a case, the family-owned corporations prefer the gradual transformation process into the public venture corporation. 
Part Three: Status Quo of the Corporate Governance in Saudi Arabia.

Corporate governance used to be a nascent subject in the MENA region including Saudi Arabia until the last decade. In 2005, the Organization for Economic Cooperation and Development (“OECD”) established a Working Group on Improving Corporate Governance in the Middle East and North Africa within the framework of the MENA-OECD Initiative on Governance and Investment for Development. The involvement of the OECD is not a coincidence since it is recognized as the international standards-setter best practices in corporate governance. The Working Group is comprised of representatives of 18 countries of the MENA region including Saudi Arabia and serves as a platform for the exchange of views among the participants and their OECD counterparts. A trend of regulating corporate governance began in Oman 2002 by establishing institutions spreading awareness and training on the importance of corporate governance and most significantly the Institute for Corporate Governance in Dubai (Koldertsova 2010). The six GCC member states signed the Dubai Declaration on Corporate Governance in 2006 which confirmed their conviction of the importance of corporate governance for their economic development and financial stability and their pledge to strengthen the underlying regulatory framework. Countries in the region also embarked on regulating corporate governance including Saudi Arabia.

There are several rules and regulations that support the implementation of corporate governance in Saudi listed companies. In 1985, the Ministry of Commerce and Industry issued the Disclosure and Transparency standard. Corporate governance is supported by issuing this standard because, disclosure and transparency is considered to be one of the most important elements of corporate governance best practice. The action of issuing this standard was one of the important decisions in the development of accounting and reporting practices in Saudi Arabia because the disclosure requirements had been very low beforehand (AlMulhem, 1997). The second Rules of corporate governance in Saudi Arabia consist of the Capital Market Law of 2003 and regulations issued by the Board of the Capital Market Authority established by the Capital Market Law. The Board of the Capital Market Authority has used the powers given to it and issued Corporate Governance Regulations governing issues concerning corporate governance.

The latest progression of corporate governance in Saudi Arabia has witnessed the development and issuing of the code of corporate governance in the year 2006. The code was prepared to harmonize with international standards of corporate governance such as the OECD principles. It contains three main parts: the Rights of Shareholders and the General Assembly, Disclosure and Transparency, and Board of Directors.

Corporate Governance Regulation in the Kingdom of Saudi Arabia Issued by the Board of Capital Market Authority Pursuant to Resolution No. 1/212/2006 dated 10/21/1427H (corresponding to 11/12/2006) based on the Capital Market Law issued by Royal Decree No. M/30 dated 6/2/1424AH Amended by Resolution of the Board of the Capital Market Authority Number 1-1-2009 Dated 1/8/1430H Corresponding to 1/5/2009G.

The Capital Market Law of 2003 was a critical step in improving corporate governance in Saudi Arabia. This law governs the Saudi capital market, in which shares of publicly held Saudi corporations are traded. The Capital Market Law created the Capital Market Authority, which was given powers to issue regulations that regulate the Saudi capital market. Until the Capital Market Authority was established in 2003, the Saudi Arabian Monetary Agency was the government body charged with regulating and monitoring market activities. The Capital Market Authority is now the sole regulator and supervisor of the Saudi capital market; it is charged with the issuance of the required rules and regulations to protect investors and ensure fairness and efficiency in the market.

The ownership of shares of corporations traded in the Saudi market generally fall into one of the following three categories: corporations in which the government or one or more of its agencies or entities own a controlling number of shares and the remainder are dispersed among other shareholders; corporations in which one or more non-government shareholders own a controlling number of shares and the remainder are dispersed among other shareholders; and corporations in which shares are dispersed among many shareholders, none of whom hold a controlling interest.

The Capital Market Law was enacted in 2003 to help sustain growth in the Saudi economy by attracting investors. To achieve this goal, the Capital Market Law furnishes investors with protections such as a required disclosure process and prohibition of manipulation of the market and insider trading. Required rules and regulations issued pursuant to the Capital Market Law are to protect investors and ensure fairness and efficiency in the market. Disclosure and transparency play a major rule in reducing the fraud, deception, and manipulation that may impede the Saudi market. The Capital Market Law created the following: Capital Market Authority, Securities market, Securities Deposit Center, Securities Settlement Committee, and Appeals Committee. The promotion of private-sector (foreign and domestic) investment is an important part of Saudi Arabia's economic program, in order to diversify its economy away from oil, foster GDP growth, and create job opportunities for its young labor force. Saudi Arabia has recently enacted many legal reforms, one of the most important of which includes an attempt to improve its system of corporate governance, the Capital Market Law. One reason for reforms was an attempt to improve Saudi Arabia's corporate governance structure and its 
competitiveness among other countries. The initiative was launched in 2006 to enact reforms and investments aimed at developing the Kingdom's private sector and to position Saudi Arabia among the world's top competitive economies. As a result of recent reforms improving Saudi Arabia's business environment, by 2010 Saudi Arabia's rank in the ease of doing business had risen rapidly to reach eleventh position. The following table No.1 shows the Saudi rank among the top countries in the ease of doing business.

Table No.1: the Saudi rank among the top countries in the ease of doing business

\begin{tabular}{|l|l|l|l|l|l|l|l|l|l|l|}
\hline Economy & Rank & A & B & C & D & E & F & G & H & I \\
\hline Singapore & 1 & 4 & 2 & 15 & 6 & 2 & 4 & 1 & 13 & 2 \\
\hline Hong Kong SAR, China & 2 & 6 & 1 & 56 & 2 & 3 & 3 & 2 & 2 & 15 \\
\hline New Zealand & 3 & 1 & 5 & 3 & 2 & 1 & 26 & 28 & 9 & 16 \\
\hline United Kingdom & 4 & 17 & 16 & 22 & 2 & 10 & 16 & 15 & 23 & 7 \\
\hline United States & 5 & 9 & 27 & 12 & 6 & 5 & 62 & 20 & 8 & 14 \\
\hline Denmark & 6 & 27 & 10 & 30 & 15 & 28 & 13 & 5 & 30 & 5 \\
\hline Canada & 7 & 3 & 29 & 37 & 32 & 5 & 10 & 41 & 58 & 3 \\
\hline Norway & 8 & 33 & 65 & 8 & 46 & 20 & 18 & 9 & 4 & 4 \\
\hline Ireland & 9 & 11 & 38 & 78 & 15 & 5 & 7 & 23 & 37 & 9 \\
\hline Australia & 10 & 2 & 63 & 35 & 6 & 59 & 48 & 29 & 16 & 12 \\
\hline Saudi Arabia & 11 & 13 & 14 & 1 & 46 & 16 & 6 & 18 & 140 & 65 \\
\hline
\end{tabular}

Where:

$\mathrm{A}=$ Starting a Business

$\mathrm{B}=$ Dealing with Construction Permits

$\mathrm{C}=$ Registering Property

$\mathrm{D}=$ Getting Credit

$\mathrm{E}=$ Protecting Investors

$\mathrm{F}=$ Paying Taxes

$\mathrm{G}=$ Trading Across Borders

$\mathrm{H}=$ Enforcing Contracts

$\mathrm{I}=$ Closing a Business

The following table No.2 compares the investors' protection measurement indicator given to the following countries by Doing Business (administered by The International Bank for Reconstruction and Development / The World Bank).

Table No.2: compares the investors' protection measurement indicator

\begin{tabular}{|c|c|c|c|c|}
\hline Economy & $\begin{array}{l}\text { This measure of the } \\
\text { transparency } \\
\text { transactions has } 5 \\
\text { components. } \\
\text { Extent of disclosure index } \\
(0-10)\end{array}$ & $\begin{array}{l}\text { This measure of liability } \\
\text { for self-dealing by } \\
\text { directors has } \\
\text { components. } \\
\text { Extent of director } \\
\text { liability index }(0-10)\end{array}$ & $\begin{array}{l}\text { This measure of shareholders' } \\
\text { ability to sue officers and } \\
\text { directors for misconduct has } 6 \\
\text { components. } \\
\text { Ease of shareholder suits index } \\
(0-10)\end{array}$ & $\begin{array}{l}\text { Strength } \\
\text { investor } \\
\text { protection index } \\
(0-10)\end{array}$ \\
\hline Saudi Arabia & 9 & 8 & 4 & 7 \\
\hline United States & 7 & 9 & 9 & 8.3 \\
\hline
\end{tabular}

This table provides some indication of the degree of investor protections in these countries/economies by measuring the strength of minority shareholder protections concerning transparency of directors' transactions, liability for self-dealing, and shareholders' ability to sue officers and directors for misconduct.

A recent empirical study showed that $57 \%$ of Saudi listed corporations had recognized self-regulatory corporate governance policies. This study further proposed that a greater number of the share investors in the Saudi exchange were more willing to invest in the shares of the listed corporations that had put into practice both the Corporate Governance Code (CGC) and their self-regulatory corporate governance policies (Saleh Al Shaalan, 2007).

Many Saudi corporate governance observers have argued about the aforesaid percentage, and believe that the study has not correctly displayed the number of listed corporations with self-regulatory corporate governance policies. In reality, the total numbers of listed corporations that have recognized self-regulatory corporate governance policies are no more than twenty-five out of 150 , which would mean a current percentage of $17 \%$.

In the framework of this research, the focus is on Saudi listed corporations, which number 150. Moreover, it is worth noting that the number of the Saudi family non-listed companies is more or less 11,000 companies outside the stock exchange. These non-listed companies do not have corporate governance selfregulatory policies even if the Capital Market Authority is trying to inspire the applications and the implementation of corporate governance for these non-listed companies. The Capital Market Authority is also encouraging non-listed companies to become listed companies, hence achieving a diversity of advantages. For instance, when the family non-listed companies join the stock exchange and become listed companies this 
contributes to the development of the Saudi economy, while sustaining the principle of Corporate Social Responsibility (CSR). In particular, family non-listed companies obtain a variety of advantages when joining the stock exchange and becoming listed companies; such as increasing company capital, improving their company's professional reputation, and tackling the dilemma of loss of shares for family members on the death of the founder(Ahmed Al Othaim,2008).

\section{Part Four: Results and recommendations:}

The research has concluded the following results:

- Corporate governance concept includes several economic, legal, administrative, accounting, social or ethical dichotomies because of the disagreement on its common definition or concept.

- Corporate governance spreads widely after the occurrence of many economic declines and crises for several economic giant units.

- Corporate governance term pays attention to achieving disclosure and transparency in all information particularly the financial information which has an effective role in realizing the objectives of the economic units' beneficiaries.

- Corporate governance helps increase the financing availability and the potentiality of having cheapfinancing resources. Therefore, its importance is increasingly growing particularly for the developing countries.

- Governance's activities and its proper implementation require comprehensive statistics and information accessible to all individuals of the society.

- Adoption of corporate governance within the public sector is fundamental for the economic development, growth and reform.

- Governance adds nothing new as its principles focus on the rights of shareholders, employees or the aspects of disclosure and accounting. These are actually regulated matters according to the laws. However, their practical implementation is not sound enough such as the taxation law, financial legislations and the law of work and social securities. It is evident that the problems dwell in the state's public atmosphere and the activation of the state of law.

- Governance requires a code of ethics, a matter which is not much practically useful unless there are effective controlling authorities.

- The existence of a large number of corporations classified under the small and medium enterprises and most of them are family-owned corporations. Thus, it is hardly to implement governance in an appropriate way.

- The auditing companies are not actually dependent from their customers so that governance can be activated.

In light of the above-mentioned results, the study introduces the following recommendations in order to implement the practices principles of the prudent administration authorities or governance:

- Necessity for devising educational curricula urging for collective work.

- Necessity for issuing legislations to protect junior investors.

- Decisive and strict punishment and reward principle in the public and private administration.

- Necessity for making legislation for opened venture corporations in order to create a scrutinizing committee.

- Holding actual seminars, and workshops to help promote the concepts of prudent administration or governance.

- Accreditation of the administration's privatization before the ownership in the public sector.

- Benefiting from the failure of other experiences due to the individual work. There are many experiences over the world.

- The accounting expert profession should be given the full independence.

- Reinforcement of the effectiveness of the controlling authorities and bodies' roles.

- Existence of effective system of electronic circulation.

- Existence of effective entry rules in the stock market which ensures the non-inclusion of small or losing corporations.

- Existence of auditing and accounting criteria consistent with the international criteria.

- Corporations should regularly or quarterly submit reviewed and accredited reports from neutral parties.

- Cultural awareness of investors and employees through different mass media.

- The necessity of practical and scientific rehabilitation for the members of internal auditing administrations in order to assimilate the principles and criteria of governance.

- The corporations' size (small, medium or big) should be taken into considerations when issuing the governance criteria. 
- The participation of public and private sectors and the academicians in devising the criteria of governance.

- Activation of laws related to corporate governance and the issue of supplementary laws in order to avoid the current legal hiatus.

- Accreditation of international accounting criteria in issuing reports, financial disclosure, corporations' figures and granting the full independence for the auditing and accounting profession.

Finally, whenever the good implementation of corporate governance's principles occurs soundly, it will represent the path of progress to individuals, institutions and the society at large. It ensures investors to achieve reasonable profitability for their investments. Such mechanisms ensure as well the sound and strength of the institutions' performance. Thus, it sustains and stabilizes the progress of financial markets, economies and societies.

\section{References}

[1]. Afifi, Sedik, Mohamed. "Special Issues of Social Administration: Transparency, Liability, Partnership." Symposium of Social Administration System and Development Continuity. Cairo, July, 2003.

[2]. Ahmed Al Othaim, Family Corporate Governance, King Fahd National Library, Riyadh, 2008

[3]. Alamgir, M. (2007). Corporate Governance: A Risk Perspective, paper presented to: Corporate Governance and Reform: Paving the Way to Financial Stability and Development, a conference organized by the Egyptian Banking Institute, Cairo, May 27-8.

[4]. Al-Essawy, Ibrahim (2003). Development in a Changeable World: A Study of Development's Concept and Indicators. Cairo: Dar El-Shrouk.

[5]. Al-Mulhem, Adnan Abdullah. (1997). an Empirical Investigation of the Level of Financial Disclosure by Saudi Arabian Corporations (PhD Dissertation), the University of Hull, Hull.

[6]. Andrei Shleifer and Robert Vishny, (2003) "A Survey of Corporate Governance," The Journal of Finance 52 (2/January): 7.37.

[7]. Azab, B., (2007): The Role of Commercial Banks in Promoting Corporate Governance of their Clients, paper presented to: Corporate Governance and Reform: Paving the Way to Financial Stability and Development, a conference organized by the Egyptian Banking Institute, Cairo, May 7-8.

[8]. Bis., (2006): Enhancing corporate governance for banking organizations, Basel Committee on Banking Supervision.

[9]. Charles P. Oman, (2005): "Corporate Governance and National Development," OECD Development Center, Technical Papers, No. 180.

[10]. Christopher Scott (London School of Economics) (2005, Measuring Up to the Measurement Problem. "The Role of Statistics in Evidence-Based Policy-Making", PARIS 21.

[11]. Fawzy, S. (April 2003). Assessment of Corporate Governance in Egypt. Working Paper No. 82. Egypt, the Egyptian center for Economic Studies.

[12]. Freeland, C. (2007) Basel Committee Guidance on Corporate Governance for Banks, Stability and Development, a conference organized by the Egyptian Banking Institute, Cairo, May 7-8

[13]. Hesil, Mark (2001). "Practices of Administration Authorities, Center for international Private Enterprises in Collaboration with Mid-Europe Universities Institution.

[14]. International Transparency Organization (2005). Arab Fairness System for Fighting against Corruption.

[15]. Iskander, M. and N. Chamlou. (2002). Corporate Governance: A Framework for Implementation. PP: 119-137. Published in: Globalization and Firm Competitiveness in the Middle East and North Africa Region, edited by: S. Fawzy. Washington: World Bank.

[16]. Koldertsova, Alissa "The Second Corporate Governance Wave in the Middle East and Africa" OECD Journal: Financial Markets and Trends, Vol. 2010, No. 1, February, 2010.

[17]. National Bank of Egypt. Practices Technique of the Corporations' Prudent Administration: Corporate Governance. Economic Newsletter, $2^{\text {nd }}$ Edition, Vol. No. 56, 2003.

[18]. OECD Development Center, Criteria of Corporate Governance, Technical Papers, No. 217.

[19]. Rafael La Porta, Florencio Lopez De Silanes, Andrei Shleifer, and Robert Vishny, (1997) "Legal Determination of External Finance," The journal of Finance 52 (July): 113150.

[20]. Report on the Arab Human Development, (2002, 2003, and 2004).

[21]. Report on the World Bank, (2002). "Building Market Institutions".

[22]. Saleh Al Shaalan, Corporate Governance in Saudi Joint Stock Companies, Arabic edition, Unpublished Master Dissertation, King Saud University, 2007.

[23]. Security (Coalition for Fairness and Liability" "Liberty of Knowledge, Acquaintance, are the Bases of Transparency and Liability", February, 2006

[24]. World Bank, "Statistical Capacity Building- STATCAP"

[25]. Youssif, Mohamed, Hassan. "Determinants and Criteria of Corporate Governance with Special Reference to Its Implementation in Egypt, National Investment Bank, July 2007. 